\title{
Evaluation of the DWPF Cold Chem Dissolution Method with Tank 7 and Tank 51 Radioactive Sludge
}

February 17, 2004

Unclassified

Does Not Contain Unclassified Controlled Nuclear Information (UCNI)

Westinghouse Savannah River Company

Savannah River Site

Aiken, SC 29808 
This document was prepared in conjunction with work accomplished under Contract No. DE-AC09-96SR18500 with the U. S. Department of Energy.

\section{DISCLAIMER}

This report was prepared as an account of work sponsored by an agency of the United States Government. Neither the United States Government nor any agency thereof, nor any of their employees, makes any warranty, express or implied, or assumes any legal liability or responsibility for the accuracy, completeness, or usefulness of any information, apparatus, product or process disclosed, or represents that its use would not infringe privately owned rights. Reference herein to any specific commercial product, process or service by trade name, trademark, manufacturer, or otherwise does not necessarily constitute or imply its endorsement, recommendation, or favoring by the United States Government or any agency thereof. The views and opinions of authors expressed herein do not necessarily state or reflect those of the United States Government or any agency thereof.

This report has been reproduced directly from the best available copy.

Available for sale to the public, in paper, from: U.S. Department of Commerce, National Technical Information Service, 5285 Port Royal Road, Springfield, VA 22161, phone: (800) 553-6847, fax: (703) 605-6900

email: orders@ntis.fedworld.gov

online ordering: http://www.ntis.gov/help/index.asp

Available electronically at http://www.osti.gov/bridge

Available for a processing fee to U.S. Department of Energy and its contractors, in paper, from: U.S. Department of Energy, Office of Scientific and Technical Information, P.O. Box 62, Oak Ridge, TN 37831-0062,

phone: (865)576-8401,

fax: (865)576-5728

email: $\underline{\text { reports@ adonis.osti.gov }}$ 
Keywords:

Analytical Methods

Process Control

Sludge Characterization

Retention:

Permanent

Classification: U

\section{REVIEWS AND APPROVALS}

D. R. Click

February 17, 2004

D. R. Click, Author

C. J. Coleman, Technical Reviewer

T. L. Fellinger, Manager, Spectroscopic Research \& Instrumental Analysis

L. M. Chandler, Manager, Analytical Development Section
Date

Date

Date

Date

Westinghouse Savannah River Company

Savannah River Site

Aiken, SC 29808

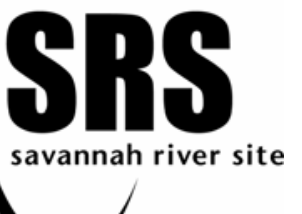




\section{TABLE OF CONTENTS}

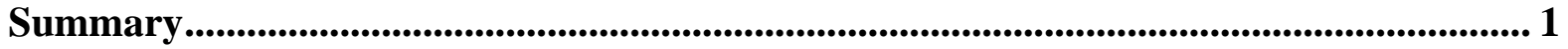

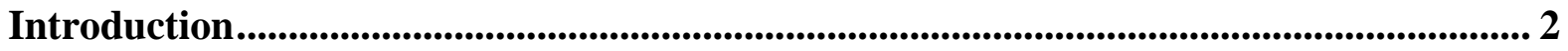

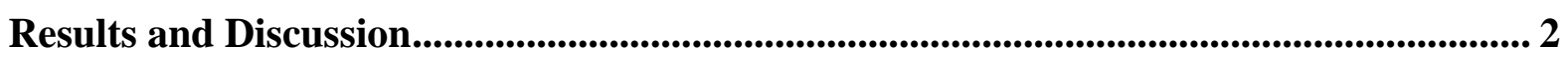

Conclusions ............................................................................................................................. 9

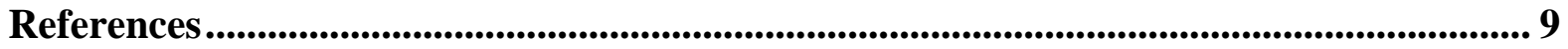

\section{LIST OF TABLES}

Table 1 Comparison of washed $3^{\text {rd }}$ Tank 7 sample digestion results $\left(\mathrm{Na}_{2} \mathrm{O}_{2}\right.$ Fusion Digestion, DWPF cold chem method, hot HF- $\mathrm{HNO}_{3}$ and hot Aqua Regia). Values are presented on a wt $\%$ wet slurry basis.............................................................................

Table 2 Comparison of Tank 51 sample digestion results $\left(\mathrm{Na}_{2} \mathrm{O}_{2}\right.$ Fusion Digestion, DWPF cold chem method, hot $\mathrm{HF}-\mathrm{HNO}_{3}$ and hot Aqua Regia). Values are presented on a wt\% dried solids basis.

Table 3 Statistical analysis results of the Tank $511^{\text {st }}$ SRAT product Digestion methods not connected by the same letter for each element are significantly different at the $95 \%$ confidence interval.

Table 4 ARG-1 Glass Standard Results for the hot $\mathrm{HF}-\mathrm{HNO}_{3}$, DWPF Cold Chem Method, hot Aqua Regia, , and the $\mathrm{Na}_{2} \mathrm{O}_{2}$ Fusion Digestions.

\section{LIST OF ACRONYMS}

$\begin{array}{ll}\text { ADS } & \text { Analytical Development Section } \\ \text { DWPF } & \text { Defense Waste Processing Facility } \\ \text { SRAT } & \text { Slurry Receipt and Adjustment Tank } \\ \text { SRTC } & \text { Savannah River Technology Center } \\ \text { WSRC } & \text { Westinghouse Savannah River Company } \\ \text { CXRD } & \text { Contained X-Ray Diffraction }\end{array}$




\section{EVALUATION OF THE DWPF COLD CHEM DISSOLUTION METHOD WITH TANK 7 AND TANK 51 RADIOACTIVE SLUDGE}

\section{Summary}

Dissolution experiments were conducted on radioactive sludge from Tank 7 , before transfer of the contents of Tank 7 to Tank 51, and the subsequent sludge in Tank 51 to evaluate the effectiveness of the DWPF Cold Chem Method. The DWPF Cold Chem Method is a room temperature $\mathrm{HF}-\mathrm{HNO}_{3}$ dissolution method ${ }^{1}$ (DWPF Cold Chem Method) used in the DWPF on the Slurry Receipt and Adjustment Tank (SRAT) samples in preparation for instrumental analysis. Four types of dissolutions experiments were carried out, the DWPF Cold Chem Method, hot aqua regia, sodium peroxide fusion and hot $\mathrm{HF}-\mathrm{HNO}_{3}$. The hot $\mathrm{HF}-\mathrm{HNO}_{3}$ digestion is modified version of the DWPF method that incorporates a heating step. The hot aqua regia and sodium peroxide fusion digestions were included as reference digestions. The resulting solutions from all the sludge digestions were analyzed by ICP-ES (Inductively Coupled Plasma Emission Spectroscopy). Visual observations and ICP-ES results were used to evaluate the effectiveness of the DWPF Cold Chem by comparison to the hot aqua regia, sodium peroxide fusion and the hot $\mathrm{HF}-\mathrm{HNO}_{3}$ digestions.

The data and experimental observations support the following conclusions:

- The DWPF Cold Chem Method seemed to be effective at dissolving initial species of radioactive sludge, but concurrent precipitation of insoluble mixed-metal fluoride salts was observed in both the Tank 7 and Tank 51 Cold Chem digestion solutions.

- Complete dissolution, by visual observation, was achieved with a modified hot $\mathrm{HF}-\mathrm{HNO}_{3}$ digestion. This was done as an alternative to the DWPF room-temperature acid dissolution.

Recommendations to the DWPF for Applications to Sludge Batch 3 based on studies to date:

- A dissolution study needs to be performed on a dip sample that consists of the final composition of the next sludge feed to the DWPF.

- Based on data collected from these experiments, a hot $\mathrm{HF}-\mathrm{HNO}_{3}$ digestion should be used for Sludge Batch 3. This digestion achieved complete dissolution of the sludge solids. It may also be possible to achieve complete digestion using the DWPF Cold Chem Method by the simple addition of boric acid as the dilution media in the second dilution step of the DWPF Cold Chem procedure but further investigation is needed.

- If incomplete dissolution is observed in a digestion, the ICP results from the incomplete digestion should be compared to another type of digestion (sodium peroxide fusion, hot aqua regia, or mixed acid) to determine if there is a practical difference in the results in terms of processability of the sludge.

- Every sludge batch should be tested because as the composition of the sludge changes the digestion methods may not be as effective. 


\section{Introduction}

A sample of the sludge feed received into the Defense Waste Processing Facility (DWPF) is typically dissolved using a room temperature $\mathrm{HF}-\mathrm{HNO}_{3}$ acid dissolution (i.e. DWPF Cold Chem Method). The Cold Chem Method is convenient (as opposed to tandem dissolutions using aqua regia and peroxide fusion digestions) and has been shown to be reliable in the past. However, it is necessary to digest a sample of each new sludge batch processed by the DWPF (using the DWPF Cold Chem Method) to ensure the digestion method works.

The Analytical Development Section (ADS) of the Savannah River Technology Center (SRTC) has tested the DWPF Cold Chem Method on simulant sludge and radioactive waste tank samples to determine if it will be adequate for use in the DWPF. Two phases of testing were completed. The first phase of this testing was done by Charles Coleman of ADS with Sludge Batch 3 simulant and glass standards. Excellent results were obtained and the results have been reported previously. ${ }^{2}$

The second phase of the testing involved using the Cold Chem Method digestion on radioactive sludge from Tank 7 and subsequent samples from Tank 51. SRTC received a Tank 7 sample (HLW designation FTF-175 - FTF-179) in February of 2003 for analysis, which was shipped to the Shielded Cells of SRTC prior to transfer of Tank 7 waste to Tank 51. In July of 2003, a Tank 51 sample (HLW designation HFT-E-03-76) was shipped to the Shielded Cells of SRTC for analysis. This report discusses digestion results using the DWPF cold chem dissolution method on radioactive sludge.

\section{Results and Discussion}

\section{$\underline{\text { Tank } 7}$}

The Tank 7 sample that was analyzed (last of three dip samples, $\sim 80 \mathrm{~mL}$ ) was received from the Tank Farms in February of 2003. After initial cation and anion analysis, it was washed with inhibited water (aqueous solution of $0.015 \mathrm{M} \mathrm{NaOH}$ and $0.015 \mathrm{M} \mathrm{NaNO}_{2}$ ) to lower the Na concentration to match previous sludge batches processed by the DWPF (Sludge batches 1 and 2 were both washed to an approximate sodium molarity of $0.5 \mathrm{M}$, this sample was washed to $0.6 \mathrm{M} \mathrm{Na}$ ). At the time of these experiments, the final sodium concentration of Sludge Batch 3 had not been determined. The slurry was then dissolved using a sodium peroxide fusion $^{3}$, hot aqua regia digestion ${ }^{4}$ and the DWPF Cold Chem method. A fourth digestion was also done in which the DWPF Cold Chem method was modified. The procedure for the modified digestion involved heating the radioactive slurry with HF (25 mL) and $\mathrm{HNO}_{3}(25 \mathrm{~mL})$ at $100{ }^{\circ} \mathrm{C}$ in a microwave vessel for two hours (3 hours if more than four samples). This is similar to the procedure used for a hot aquaregia digestion. The results of the four digestions are shown in Table 1 on a wet slurry basis. Solids were visible in the solution from the DWPF Cold Chem digestion. Furthermore, after several weeks of storage in the cells, light colored solids were deposited in the bottles containing the digestion solutions from the hot $\mathrm{HF}_{-} \mathrm{HNO}_{3}$ procedure. It is likely that these solids are mixed metal fluoride salts. $\mathrm{Na}_{3} \mathrm{AlF}_{6}$ and $\mathrm{NaMgAlF}_{6}$ had previously precipitated from the Cold Chem Method digestion solutions of the first Tank 7 samples (December 2001, HLW designation 
FTF-152 - FTF-156) and were characterized by Contained X-Ray Diffraction (CXRD). No solids were observed in either the hot aqua regia or sodium peroxide fusion digestion solutions.

The elemental weight percent results shown in Table 1, on a slurry basis, do not seem to vary significantly despite the precipitation of visible solids in the DWPF Cold Chem Method digestion solutions. If the solids precipitate out as small particles (1-10 microns in size), the analysis will not be affected because the particles can be effectively carried up into the plasma along with the nebulized solution in the ICP-ES instrument.

Table 1. Comparison of washed $3^{\text {rd }}$ Tank 7 sample digestion results (Sodium Peroxide Fusion, DWPF Cold Chem method, hot $\mathrm{HF}-\mathrm{HNO}_{3}$ and hot Aqua Regia). Values are presented on a wt\% wet slurry basis.

\begin{tabular}{|c|c|c|c|c|c|c|c|c|}
\hline Element & $\begin{array}{l}\mathrm{Na}_{2} \mathrm{O}_{2} \\
\text { Fusion } \\
\text { Digestion* }\end{array}$ & $\%$ RSD & $\begin{array}{l}\text { DWPF } \\
\text { Cold Chem } \\
\text { Digestion* }\end{array}$ & $\%$ RSD & $\begin{array}{l}\text { Hot HF- } \\
\mathrm{HNO}_{3} \\
\text { Digestion* }\end{array}$ & $\%$ RSD & $\begin{array}{l}\text { Hot Aqua } \\
\text { Regia } \\
\text { Digestion* }\end{array}$ & $\%$ RSD \\
\hline $\mathrm{Al}$ & 3.03E-01 & $7.9 \mathrm{E}+00$ & 2.93E-01 & $8.7 \mathrm{E}+00$ & 3.13E-01 & $1.2 \mathrm{E}+00$ & $3.24 \mathrm{E}-01$ & 6.2E-01 \\
\hline B & $<2.76 \mathrm{E}-01$ & NA & $<2.68 \mathrm{E}-01$ & NA & $<2.55 \mathrm{E}-01$ & NA & $<2.26 \mathrm{E}+00$ & NA \\
\hline $\mathrm{Ba}$ & $1.90 \mathrm{E}-02$ & $7.4 \mathrm{E}+00$ & $1.87 \mathrm{E}-02$ & $8.6 \mathrm{E}+00$ & $2.15 \mathrm{E}-02$ & $4.6 \mathrm{E}+00$ & $<2.35 \mathrm{E}-02$ & NA \\
\hline $\mathrm{Ca}$ & \begin{tabular}{|l|}
$1.30 \mathrm{E}-01$ \\
\end{tabular} & $8.2 \mathrm{E}+00$ & 1.25E-01 & $8.7 \mathrm{E}+00$ & 1.34E-01 & 6.9E-01 & $<7.08 \mathrm{E}-01$ & NA \\
\hline $\mathrm{Cd}$ & 7.50E-03 & $9.4 \mathrm{E}+00$ & 7.55E-03 & $7.9 \mathrm{E}+00$ & 8.35E-03 & $2.5 \mathrm{E}+00$ & $<3.12 \mathrm{E}-02$ & NA \\
\hline $\mathrm{Cr}$ & \begin{tabular}{|l|}
$1.55 \mathrm{E}-02$ \\
\end{tabular} & $4.6 \mathrm{E}+00$ & $1.51 \mathrm{E}-02$ & $8.6 \mathrm{E}+00$ & $2.37 \mathrm{E}-02$ & $3.8 \mathrm{E}+01$ & $<2.66 \mathrm{E}-02$ & NA \\
\hline $\mathrm{Cu}$ & $5.50 \mathrm{E}-03$ & $1.3 \mathrm{E}+01$ & 5.55E-03 & $9.0 \mathrm{E}+00$ & $5.75 \mathrm{E}-03$ & $6.1 \mathrm{E}+00$ & $<2.48 \mathrm{E}-02$ & NA \\
\hline $\mathrm{Fe}$ & $3.13 \mathrm{E}+00$ & $7.8 \mathrm{E}+00$ & $3.02 \mathrm{E}+00$ & $8.7 \mathrm{E}+00$ & $3.32 \mathrm{E}+00$ & $1.1 \mathrm{E}+00$ & $3.49 \mathrm{E}+00$ & $1.6 \mathrm{E}+00$ \\
\hline Gd & $<4.50 \mathrm{E}-03$ & NA & $<4.50 \mathrm{E}-03$ & NA & $<4.30 \mathrm{E}-03$ & NA & $<4.22 \mathrm{E}-02$ & NA \\
\hline K & $<1.63 \mathrm{E}+00$ & NA & $<1.57 \mathrm{E}+00$ & NA & $<1.51 \mathrm{E}+00$ & NA & $<1.49 \mathrm{E}+01$ & NA \\
\hline $\mathrm{Mg}$ & 8.15E-02 & $7.8 \mathrm{E}+00$ & 7.88E-02 & $8.8 \mathrm{E}+00$ & 8.29E-02 & 9.4E-01 & $<9.67 \mathrm{E}-02$ & NA \\
\hline Mn & $1.19 \mathrm{E}+00$ & $7.8 \mathrm{E}+00$ & $1.15 \mathrm{E}+00$ & $8.8 \mathrm{E}+00$ & $1.25 \mathrm{E}+00$ & $3.0 \mathrm{E}+00$ & $1.29 \mathrm{E}+00$ & $1.6 \mathrm{E}+00$ \\
\hline $\mathrm{Na}$ & NA & NA & $1.92 \mathrm{E}+00$ & $8.7 \mathrm{E}+00$ & $2.02 \mathrm{E}+00$ & 9.9E-01 & $1.78 \mathrm{E}+00$ & $4.0 \mathrm{E}+00$ \\
\hline $\mathrm{Ni}$ & 4.73E-01 & $7.8 \mathrm{E}+00$ & 4.57E-01 & $8.7 \mathrm{E}+00$ & 5.03E-01 & $8.2 \mathrm{E}-01$ & 5.13E-01 & $3.1 \mathrm{E}+00$ \\
\hline $\mathrm{P}$ & $8.40 \mathrm{E}-02$ & $8.4 \mathrm{E}+00$ & 8.12E-02 & $8.7 \mathrm{E}+00$ & 7.66E-02 & $1.0 \mathrm{E}+00$ & $<7.58 \mathrm{E}-01$ & NA \\
\hline $\mathrm{Pb}$ & $<4.20 \mathrm{E}-02$ & NA & $<4.07 \mathrm{E}-02$ & NA & $<3.89 \mathrm{E}-02$ & NA & $<3.84 \mathrm{E}-01$ & NA \\
\hline $\mathrm{Sb}$ & $<2.55 \mathrm{E}-02$ & NA & $<2.50 \mathrm{E}-02$ & NA & $<2.38 \mathrm{E}-02$ & NA & $<2.36 \mathrm{E}-01$ & NA \\
\hline Si & 3.41E-01 & $7.7 \mathrm{E}+00$ & 3.29E-01 & $8.7 \mathrm{E}+00$ & 3.31E-01 & $2.5 \mathrm{E}+00$ & $<5.78 \mathrm{E}-02$ & NA \\
\hline Sn & $<4.20 \mathrm{E}-02$ & NA & $<4.06 \mathrm{E}-02$ & NA & $<3.87 \mathrm{E}-02$ & NA & $<3.38 \mathrm{E}-01$ & NA \\
\hline $\mathrm{Sr}$ & $3.15 \mathrm{E}-02$ & $6.7 \mathrm{E}+00$ & $3.04 \mathrm{E}-02$ & $8.6 \mathrm{E}+00$ & 3.39E-02 & $2.7 \mathrm{E}+00$ & $<1.56 \mathrm{E}-01$ & NA \\
\hline $\mathrm{Ti}$ & 3.00E-03 & $0.0 \mathrm{E}+00$ & 2.85E-03 & $7.0 \mathrm{E}+00$ & 3.00E-03 & $4.7 \mathrm{E}+00$ & $<9.37 \mathrm{E}-03$ & NA \\
\hline $\mathrm{U}$ & $1.06 \mathrm{E}+00$ & $7.8 \mathrm{E}+00$ & $1.03 \mathrm{E}+00$ & $8.7 \mathrm{E}+00$ & $1.08 \mathrm{E}+00$ & $1.9 \mathrm{E}+00$ & $1.17 \mathrm{E}+00$ & NA \\
\hline
\end{tabular}

*All averages are based upon two replicate dissolutions and ICP-ES determinations. NA = Not Applicable 


\section{$\underline{\text { Tank } 51}$}

After Tank 7 sludge was transferred to Tank 51, SRTC (Savannah River Technology Center) received a sample ( $\sim 5 \mathrm{~L}$ ) from Tank 51 . The Tank 51 sample was shipped to the Shielded Cells of SRTC in July of 2003. After addition of appropriate amounts of Pu and Np solutions to the sludge slurry from Tank 51, it became the sludge batch three qualification sample. A simulated SRAT run was completed with the sludge batch three qualification sample in September 2003, and the subsequent SRAT product was digested using the DWPF Cold Chem Digestion Method, a hot $\mathrm{HF}_{-} \mathrm{HNO}_{3}$ digestion, sodium peroxide fusion method and a hot aqua regia digestion. Each digestion was done in triplicate and the ICP-ES determinations are an average of the three digested samples except the peroxide fusion results, which are an average of two ICP-ES measurements (see Table 2). The Cold Chem Method was performed in a similar manner to the DWPF procedure. Concentrated HF (25 $\mathrm{mL}$ ) was added to the sludge slurry (enough to have $1 \mathrm{~g}$ of dried solids) and mixed for 1.5 hours. Then, concentrated $\mathrm{HNO}_{3}(25 \mathrm{~mL})$ was added and the mixture was stirred for an additional 1 hour. The mixture was serially diluted to attain a final volume of 5 liters. Once again, solids were visually observed in the digestion solution from the DWPF Cold Chem Method. The insoluble solids were isolated by filtration and characterized by CXRD. The solids were determined to be mixed-metal fluoride salts, $\mathrm{FeZrF}_{6}$ and $\mathrm{Na}_{2} \mathrm{FeAlF}_{7}$. The hot HF$\mathrm{HNO}_{3}$ digestions were performed by weighing out in a microwave vessel enough sludge slurry for each sludge sample to contain 1g of dried solids and then $25 \mathrm{~mL}$ of $\mathrm{HF}$ was added followed by immediate addition of $25 \mathrm{~mL} \mathrm{HNO}_{3}$. The mixtures were heated in the oven in the microwave vessel for three hours and then allowed to cool for one hour before being serially diluted. No visible solids were in the solutions after the heating step or after storage in the cells for several days. The peroxide fusion digestion was performed on a similar scale and once again the resulting solution was serially diluted before analysis by ICP-ES. The aqua regia digestions were performed on a smaller scale and per the ADS procedure (see reference 4). In this case, $\sim 0.25 \mathrm{~g}$ of dried solids were used and the resulting solution did not require serial dilution. The results of the digestions are shown in Table 2 on a wt $\%$ dried solids basis. ARG-1 glass of known composition was digested along with the samples from each digestion above as a check. 
Table 2. Comparison of Tank 51 sample digestion results (Sodium Peroxide Fusion, DWPF Cold Chem method, hot $\mathrm{HF}-\mathrm{HNO}_{3}$ and hot Aqua Regia). Values are presented on a wt \% dried solids basis.

\begin{tabular}{|c|c|c|c|c|c|c|c|c|}
\hline Element & $\begin{array}{l}\mathrm{Na}_{2} \mathrm{O}_{2} \\
\text { Fusion } \\
\text { Digestion* }\end{array}$ & \%RSD & $\begin{array}{l}\text { Cold Chem } \\
\text { Digestion* }\end{array}$ & $\%$ RSD & $\begin{array}{l}\text { Hot HF- } \\
\mathrm{HNO}_{3} \\
\text { Digestion* }\end{array}$ & \%RSD & $\begin{array}{l}\text { Hot Aqua } \\
\text { Regia } \\
\text { Digestion* }\end{array}$ & $\%$ RSD \\
\hline $\mathrm{Al}$ & $4.56 \mathrm{E}+00$ & $1.1 \mathrm{E}+00$ & $4.99 \mathrm{E}+00$ & $1.5 \mathrm{E}+00$ & $4.91 \mathrm{E}+00$ & $1.5 \mathrm{E}+00$ & $4.57 \mathrm{E}+00$ & 8.6E-01 \\
\hline $\mathrm{B}$ & $<3.17 \mathrm{E}-02$ & NA & $3.62 \mathrm{E}-02$ & $5.6 \mathrm{E}+00$ & $4.26 \mathrm{E}-02$ & $1.9 \mathrm{E}+01$ & $<7.70 \mathrm{E}-01$ & NA \\
\hline $\mathrm{Ba}$ & $5.00 \mathrm{E}-02$ & 1.9E-01 & $4.60 \mathrm{E}-02$ & $2.2 \mathrm{E}+00$ & $4.64 \mathrm{E}-02$ & $2.5 \mathrm{E}+00$ & $4.40 \mathrm{E}-02$ & $5.7 \mathrm{E}+00$ \\
\hline $\mathrm{Ca}$ & $1.10 \mathrm{E}+00$ & 3.1E-01 & $1.13 \mathrm{E}+00$ & 9.4E-01 & $1.14 \mathrm{E}+00$ & $1.1 \mathrm{E}+00$ & $1.08 \mathrm{E}+00$ & $1.4 \mathrm{E}+00$ \\
\hline $\mathrm{Cd}$ & 1.60E-01 & 5.6E-01 & $1.89 \mathrm{E}-01$ & $2.5 \mathrm{E}+00$ & $1.93 \mathrm{E}-01$ & $4.8 \mathrm{E}-01$ & $1.77 \mathrm{E}-01$ & $1.1 \mathrm{E}+00$ \\
\hline $\mathrm{Cr}$ & $8.28 \mathrm{E}-02$ & $1.0 \mathrm{E}+01$ & 7.95E-02 & $5.8 \mathrm{E}+00$ & 8.63E-02 & $4.5 \mathrm{E}+00$ & $8.70 \mathrm{E}-02$ & $2.6 \mathrm{E}+01$ \\
\hline $\mathrm{Cu}$ & $1.01 \mathrm{E}-02$ & $1.5 \mathrm{E}+01$ & $1.94 \mathrm{E}-02$ & $1.6 \mathrm{E}+00$ & 1.92E-02 & $1.2 \mathrm{E}+00$ & 1.82E-02 & $1.5 \mathrm{E}+01$ \\
\hline $\mathrm{Fe}$ & $1.20 \mathrm{E}+01$ & $7.2 \mathrm{E}-01$ & $1.26 \mathrm{E}+01$ & $1.7 \mathrm{E}+00$ & $1.33 \mathrm{E}+01$ & $4.6 \mathrm{E}-01$ & $1.21 \mathrm{E}+01$ & $4.8 \mathrm{E}-01$ \\
\hline $\mathrm{Gd}$ & $5.00 \mathrm{E}-02$ & 1.9E-01 & 4.15E-02 & $3.6 \mathrm{E}+00$ & $4.02 \mathrm{E}-02$ & $1.6 \mathrm{E}+00$ & $4.04 \mathrm{E}-02$ & $5.0 \mathrm{E}+00$ \\
\hline $\mathrm{Li}$ & $1.39 \mathrm{E}+00$ & $9.0 \mathrm{E}-01$ & 9.25E-01 & $5.0 \mathrm{E}+00$ & $9.70 \mathrm{E}-01$ & $3.5 \mathrm{E}+00$ & $<4.04 \mathrm{E}-02$ & NA \\
\hline $\mathrm{K}$ & $4.27 \mathrm{E}-01$ & $1.6 \mathrm{E}+00$ & $<4.56 \mathrm{E}-01$ & NA & $<4.69 \mathrm{E}-01$ & NA & $<4.53 \mathrm{E}+00$ & NA \\
\hline $\mathrm{Mg}$ & $1.15 E+00$ & $2.2 \mathrm{E}-01$ & $1.29 \mathrm{E}+00$ & $1.4 \mathrm{E}+00$ & $1.31 \mathrm{E}+00$ & 7.9E-01 & $1.29 \mathrm{E}+00$ & $1.0 \mathrm{E}+00$ \\
\hline Mn & $3.22 \mathrm{E}+00$ & 5.6E-01 & $3.59 \mathrm{E}+00$ & $1.5 \mathrm{E}+00$ & $3.65 \mathrm{E}+00$ & $3.6 \mathrm{E}-02$ & $3.49 \mathrm{E}+00$ & $1.2 \mathrm{E}+00$ \\
\hline $\mathrm{Na}$ & NA & NA & $8.99 \mathrm{E}+00$ & $2.5 \mathrm{E}+00$ & $8.81 \mathrm{E}+00$ & $2.7 \mathrm{E}+00$ & $1.22 \mathrm{E}+01$ & $1.5 \mathrm{E}+00$ \\
\hline $\mathrm{Ni}$ & $8.12 \mathrm{E}-01$ & $9.6 \mathrm{E}-01$ & $8.63 \mathrm{E}-01$ & $1.3 \mathrm{E}+00$ & $9.06 \mathrm{E}-01$ & $6.9 \mathrm{E}-01$ & $8.13 \mathrm{E}-01$ & $1.8 \mathrm{E}+00$ \\
\hline $\mathrm{P}$ & 2.77E-01 & $2.3 \mathrm{E}+01$ & 3.01E-01 & $8.8 \mathrm{E}+00$ & 2.97E-01 & $5.7 \mathrm{E}+00$ & $2.45 \mathrm{E}-01$ & $2.9 \mathrm{E}+01$ \\
\hline $\mathrm{Pb}$ & $<1.37 \mathrm{E}-01$ & NA & $<1.47 \mathrm{E}-01$ & NA & $<1.51 \mathrm{E}-01$ & NA & $<1.17 \mathrm{E}-01$ & NA \\
\hline $\mathrm{Sb}$ & 5.89E-02 & $3.3 \mathrm{E}+00$ & 5.52E-02 & $3.0 \mathrm{E}+00$ & $5.28 \mathrm{E}-02$ & $4.1 \mathrm{E}+00$ & $<7.18 \mathrm{E}-01$ & NA \\
\hline $\mathrm{Si}$ & $1.02 \mathrm{E}+00$ & $7.9 \mathrm{E}-01$ & $4.55 \mathrm{E}+00$ & $8.6 \mathrm{E}+00$ & $4.49 \mathrm{E}+00$ & $6.3 \mathrm{E}+00$ & 1.17E-01 & $3.3 \mathrm{E}+01$ \\
\hline Sn & $5.62 \mathrm{E}-02$ & $2.1 \mathrm{E}+00$ & $6.85 \mathrm{E}-02$ & $4.4 \mathrm{E}+00$ & $<6.01 \mathrm{E}-02$ & NA & $<1.16 \mathrm{E}-01$ & NA \\
\hline Sr & $2.67 \mathrm{E}-01$ & $2.4 \mathrm{E}-02$ & $2.65 \mathrm{E}-01$ & $1.1 \mathrm{E}+00$ & $2.68 \mathrm{E}-01$ & $2.9 \mathrm{E}-01$ & $2.49 \mathrm{E}-01$ & $1.7 \mathrm{E}+00$ \\
\hline $\mathrm{Ti}$ & 1.39E-02 & $1.6 \mathrm{E}+00$ & 1.13E-02 & $6.5 \mathrm{E}+00$ & $1.14 \mathrm{E}-02$ & $3.0 \mathrm{E}+00$ & $1.29 \mathrm{E}-02$ & $5.6 \mathrm{E}+00$ \\
\hline $\bar{U}$ & $4.92 \mathrm{E}+00$ & $5.2 \mathrm{E}-01$ & $5.45 \mathrm{E}+00$ & $1.7 \mathrm{E}+00$ & $5.44 \mathrm{E}+00$ & $2.7 \mathrm{E}-01$ & $5.05 \mathrm{E}+00$ & $1.1 \mathrm{E}+00$ \\
\hline $\mathrm{Zr}$ & NA & NA & $9.19 \mathrm{E}-02$ & $1.0 \mathrm{E}+00$ & $7.62 \mathrm{E}-02$ & $9.1 \mathrm{E}-01$ & $9.09 \mathrm{E}-03$ & $3.8 \mathrm{E}+01$ \\
\hline
\end{tabular}

*All averages are based upon three replicate dissolutions and ICP-ES determinations except the peroxide fusion results, which are based on two replicate samples. NA = Not Applicable.

A statistical study was done on the results from separate digestions, using JMP software ${ }^{5}$, to determine if the wt $\%$ results were significantly different at the $95 \%$ confidence level. The results are shown in Table 3. The statistical analysis results indicate that for all elements except iron and strontium, the DWPF Cold Chem Method and the hot $\mathrm{HF}-\mathrm{HNO}_{3}$ digestions were statistically equivalent. However, the difference between the average results for iron and strontium was less than $2 \%$, which is not a practical difference. This is despite the visible solids in the solution of the DWPF Cold Chem Method digestions. The elemental weight percent results shown in Table 1, on a slurry basis, do not seem to vary significantly despite the precipitation of visible solids in the DWPF Cold Chem Method digestion solutions. If the solids precipitate out as small particles (1-10 microns in size), the analysis will not be affected because the particles can be effectively carried up into the plasma along with the nebulized solution in the ICP-ES instrument. The peroxide fusion results agreed well with both the Cold Chem Method and the hot $\mathrm{HF}-\mathrm{HNO}_{3}$ digestions on some elements but are 
statistically different in regards to some of the more important elements in the sludge such as $\mathrm{Al}, \mathrm{Ca}, \mathrm{Fe}, \mathrm{Mn}, \mathrm{Na}, \mathrm{Ni}$ and $\mathrm{U}$ although the difference is no larger than $15 \%$ except in the case of sodium. The difference in the sodium values is attributed to less than optimum plasma conditions of the ICP instrument. The lithium and potassium results should also not be compared between the digestion methods for the same reason. The aqua regia digestion results are statistically different for many elements versus the Cold Chem Method and the hot $\mathrm{HF}-\mathrm{HNO}_{3}$ digestions. The differences in results are attributed to the sample preparation. For example, the aqua regia sample was prepared using less total solids and was not serially diluted before analysis. It is important to note that although a statistical difference is discernable between the different digestion methods there may not be a practical difference in terms of processability. The results of the dissolutions of the ARG-1 glass standard are shown in Table 4 for the major elements greater than $1 \mathrm{wt} \%$.

Table 3. Statistical analysis results of the Tank $511^{\text {st }}$ SRAT product. Digestion methods not connected by the same letter for each element are significantly different at the 95\% confidence interval.

\begin{tabular}{|l|l|l|l|l|}
\hline Element & $\begin{array}{l}\text { Aqua } \\
\text { Regia } \\
\text { Digestion }\end{array}$ & $\begin{array}{l}\mathrm{Na}_{2} \mathrm{O}_{2} \\
\text { Fusion } \\
\text { Digestion }\end{array}$ & $\begin{array}{l}\text { Cold } \\
\text { Chem } \\
\text { Digestion }\end{array}$ & $\begin{array}{l}\text { Hot } \\
\mathrm{HF}- \\
\mathrm{HNO}_{3} \\
\text { Digestion }\end{array}$ \\
\hline $\mathrm{Al}$ & $\mathrm{A}$ & $\mathrm{A}$ & $\mathrm{B}$ & B \\
\hline $\mathrm{Ba}$ & $\mathrm{A}$ & $\mathrm{B}$ & $\mathrm{B}$ & B \\
\hline $\mathrm{Ca}$ & A & A & B & B \\
\hline $\mathrm{Cd}$ & A & C & B & B \\
\hline $\mathrm{Cr}$ & A & A & A & A \\
\hline $\mathrm{Cu}$ & A & B & A & A \\
\hline $\mathrm{Fe}$ & A & A & B & C \\
\hline $\mathrm{Gd}$ & A & B & B & B \\
\hline $\mathrm{Mg}$ & A & B & AB & B \\
\hline $\mathrm{Mn}$ & A & B & C & C \\
\hline $\mathrm{Ni}$ & A & B & C & C \\
\hline $\mathrm{P}$ & A & A & A & A \\
\hline $\mathrm{S}$ & A & A & A & A \\
\hline $\mathrm{Sb}$ & A & A & A & A \\
\hline $\mathrm{Sr}$ & A & A & A & B \\
\hline $\mathrm{Ti}$ & A & B & B & B \\
\hline $\mathrm{U}$ & A & B & C & C \\
\hline
\end{tabular}

NA = Not Applicable. 
Table 4. ARG-1 Glass Standard results for the hot $\mathrm{HF}_{-} \mathrm{HNO}_{3}, \mathrm{DWPF}$ Cold Chem Method, hot Aqua Regia, and the $\mathrm{Na}_{2} \mathrm{O}_{2}$ Fusion Digestions.

\begin{tabular}{|c|c|c|c|c|}
\hline \multicolumn{5}{|c|}{ Hot HF-HNO ${ }_{3}{ }^{*}$} \\
\hline Element & Average & $\%$ RSD & Known Value & $\begin{array}{l}\text { \%Difference } \\
\text { (Measured vs } \\
\text { Known } \\
\text { Composition) }\end{array}$ \\
\hline $\mathrm{Al}$ & $2.12 \mathrm{E}+00$ & 7.7E-01 & $2.5 \mathrm{E}+00$ & -15.3 \\
\hline $\mathrm{Ca}$ & 9.99E-01 & $3.8 \mathrm{E}+00$ & $1.02 \mathrm{E}+00$ & -2.10 \\
\hline $\mathrm{Cr}$ & 6.34E-02 & $6.0 \mathrm{E}+00$ & $6.4 \mathrm{E}-02$ & 0.94 \\
\hline $\mathrm{Fe}$ & $9.76 \mathrm{E}+00$ & $2.8 \mathrm{E}-01$ & $9.79 \mathrm{E}+00$ & -0.26 \\
\hline $\mathrm{K}$ & $1.61 \mathrm{E}+00$ & $5.6 \mathrm{E}+00$ & $2.26 \mathrm{E}+00$ & -28.4 \\
\hline $\mathrm{Li}$ & $9.70 \mathrm{E}-01$ & $3.5 \mathrm{E}+00$ & $1.49 \mathrm{E}+00$ & -34.9 \\
\hline $\mathrm{Mg}$ & 5.21E-01 & $3.4 \mathrm{E}+00$ & 5.2E-01 & 0.19 \\
\hline $\mathrm{Mn}$ & $1.45 \mathrm{E}+00$ & 4.2E-01 & $1.46 \mathrm{E}+00$ & -0.45 \\
\hline $\mathrm{Na}$ & $5.88 \mathrm{E}+00$ & $4.3 \mathrm{E}+00$ & $8.52 \mathrm{E}+00$ & -31.0 \\
\hline $\mathrm{Ni}$ & 8.54E-01 & 3.5E-01 & $8.27 \mathrm{E}-01$ & 3.26 \\
\hline $\mathrm{Si}$ & $2.42 \mathrm{E}+01$ & $3.0 \mathrm{E}+00$ & $2.24 \mathrm{E}+01$ & 7.91 \\
\hline $\mathrm{Ti}$ & $6.68 \mathrm{E}-01$ & $2.5 \mathrm{E}+00$ & 6.9E-01 & -2.90 \\
\hline $\mathrm{Zr}$ & $9.20 \mathrm{E}-02$ & 3.4E-01 & $1.0 \mathrm{E}-01$ & -8.00 \\
\hline \multicolumn{5}{|c|}{ DWPF Cold Chem Method* } \\
\hline $\mathrm{Al}$ & $2.11 \mathrm{E}+00$ & $2.5 \mathrm{E}+00$ & $2.5 \mathrm{E}+00$ & -15.4 \\
\hline $\mathrm{Ca}$ & $1.03 \mathrm{E}+00$ & $2.7 \mathrm{E}+00$ & $1.02 \mathrm{E}+00$ & 0.74 \\
\hline $\mathrm{Cr}$ & 6.45E-02 & $3.7 \mathrm{E}+00$ & $6.4 \mathrm{E}-02$ & -0.78 \\
\hline $\mathrm{Fe}$ & $1.08 \mathrm{E}+01$ & $1.8 \mathrm{E}+01$ & $9.79 \mathrm{E}+00$ & 10.4 \\
\hline $\mathrm{K}$ & $1.56 \mathrm{E}+00$ & $2.8 \mathrm{E}+00$ & $2.26 \mathrm{E}+00$ & -30.7 \\
\hline $\mathrm{Li}$ & 9.25E-01 & $5.0 \mathrm{E}+00$ & $1.49 \mathrm{E}+00$ & -37.9 \\
\hline $\mathrm{Mg}$ & 5.17E-01 & $2.0 \mathrm{E}+00$ & 5.2E-01 & -0.58 \\
\hline $\mathrm{Mn}$ & $1.45 \mathrm{E}+00$ & $1.7 \mathrm{E}+00$ & $1.46 \mathrm{E}+00$ & -0.37 \\
\hline $\mathrm{Na}$ & $5.55 \mathrm{E}+00$ & $4.3 \mathrm{E}+00$ & $8.52 \mathrm{E}+00$ & -34.9 \\
\hline $\mathrm{Ni}$ & 8.45E-01 & $1.4 \mathrm{E}+00$ & 8.27E-01 & 2.18 \\
\hline $\mathrm{Si}$ & $2.39 \mathrm{E}+01$ & $2.8 \mathrm{E}+00$ & $2.24 \mathrm{E}+01$ & 6.49 \\
\hline $\mathrm{Ti}$ & 6.57E-01 & $1.7 \mathrm{E}+00$ & 6.9E-01 & -4.57 \\
\hline $\mathrm{Zr}$ & 9.19E-02 & $1.0 \mathrm{E}+00$ & 1.0E-01 & -8.10 \\
\hline
\end{tabular}

*All averages are based upon three replicate dissolutions and ICP-ES determinations NA = Not applicable. 
Table 4 (continued). ARG-1 Glass Standard results for the hot $\mathrm{HF}_{-} \mathrm{HNO}_{3}, \mathrm{DWPF}$ Cold Chem Method, hot Aqua Regia, and the $\mathrm{Na}_{2} \mathrm{O}_{2}$ Fusion Digestions.

\begin{tabular}{|c|c|c|c|c|}
\hline \multicolumn{5}{|c|}{ Hot Aqua Regia* } \\
\hline Element & Average & \%RSD & Known Value & $\begin{array}{l}\text { \%Difference } \\
\text { (Measured vs } \\
\text { Known } \\
\text { Composition) }\end{array}$ \\
\hline $\mathrm{Al}$ & $2.19 \mathrm{E}+00$ & $1.2 \mathrm{E}+00$ & $2.5 \mathrm{E}+00$ & -12.4 \\
\hline $\mathrm{Ca}$ & $1.01 \mathrm{E}+00$ & $3.0 \mathrm{E}+00$ & $1.02 \mathrm{E}+00$ & -0.9 \\
\hline $\mathrm{Cr}$ & 6.50E-02 & $6.5 \mathrm{E}+00$ & $6.4 \mathrm{E}-02$ & -0.98 \\
\hline $\mathrm{Fe}$ & $9.87 \mathrm{E}+00$ & $3.6 \mathrm{E}-01$ & $9.79 \mathrm{E}+00$ & 0.82 \\
\hline $\mathrm{K}$ & $<9.16 \mathrm{E}+00$ & NA & $2.26 \mathrm{E}+00$ & NA \\
\hline $\mathrm{Li}$ & $1.45 \mathrm{E}+00$ & $1.2 \mathrm{E}+00$ & $1.49 \mathrm{E}+00$ & -2.68 \\
\hline $\mathrm{Mg}$ & 5.20E-01 & $2.6 \mathrm{E}+00$ & $5.2 \mathrm{E}-01$ & 0.00 \\
\hline $\mathrm{Mn}$ & $1.47 \mathrm{E}+00$ & 3.9E-01 & $1.46 \mathrm{E}+00$ & 0.68 \\
\hline $\mathrm{Na}$ & $8.24 \mathrm{E}+00$ & $1.5 \mathrm{E}+00$ & $8.52 \mathrm{E}+00$ & -3.40 \\
\hline $\mathrm{Ni}$ & 8.27E-01 & 7.9E-01 & $8.27 \mathrm{E}-01$ & -0.36 \\
\hline $\mathrm{Si}$ & NA & NA & $2.24 \mathrm{E}+01$ & NA \\
\hline $\mathrm{Ti}$ & 6.05E-01 & $1.6 \mathrm{E}+00$ & 6.9E-01 & -12.3 \\
\hline $\mathrm{Zr}$ & $4.46 \mathrm{E}-02$ & $1.3 \mathrm{E}+01$ & $1.0 \mathrm{E}-01$ & -55.4 \\
\hline \multicolumn{5}{|c|}{$\mathrm{Na}_{2} \mathrm{O}_{2}$ Peroxide Fusion* } \\
\hline $\mathrm{Al}$ & $2.00 \mathrm{E}+00$ & $3.2 \mathrm{E}+00$ & $2.5 \mathrm{E}+00$ & -19.9 \\
\hline $\mathrm{Ca}$ & $1.04 \mathrm{E}+00$ & $9.8 \mathrm{E}-01$ & $1.02 \mathrm{E}+00$ & 1.90 \\
\hline $\mathrm{Cr}$ & \begin{tabular}{|l|}
$<1.00 \mathrm{E}-01$ \\
\end{tabular} & NA & $6.4 \mathrm{E}-02$ & NA \\
\hline $\mathrm{Fe}$ & $8.89 \mathrm{E}+00$ & $6.4 \mathrm{E}-01$ & $9.79 \mathrm{E}+00$ & -9.20 \\
\hline $\mathrm{K}$ & $<2.51$ & NA & $2.26 \mathrm{E}+00$ & NA \\
\hline $\mathrm{Li}$ & $1.39 \mathrm{E}+00$ & 9.0E-01 & $1.49 \mathrm{E}+00$ & -6.83 \\
\hline $\mathrm{Mg}$ & 4.45E-01 & $1.3 \mathrm{E}+00$ & $5.2 \mathrm{E}-01$ & -15.4 \\
\hline $\mathrm{Mn}$ & $1.31 \mathrm{E}+00$ & 7.2E-01 & $1.46 \mathrm{E}+00$ & -10.3 \\
\hline $\mathrm{Na}$ & $8.23 \mathrm{E}+00$ & $1.5 \mathrm{E}+00$ & $8.52 \mathrm{E}+00$ & -3.4 \\
\hline $\mathrm{Ni}$ & 7.44E-01 & 9.3E-01 & 8.27E-01 & -10.0 \\
\hline $\mathrm{Si}$ & $2.11 \mathrm{E}+01$ & $6.8 \mathrm{E}-01$ & $2.24 \mathrm{E}+01$ & -5.92 \\
\hline $\mathrm{Ti}$ & 6.10E-01 & $7.5 \mathrm{E}-01$ & 6.9E-01 & -11.6 \\
\hline $\mathrm{Zr}$ & NA & NA & $1.0 \mathrm{E}-01$ & NA \\
\hline
\end{tabular}

*All averages are based upon three replicate dissolutions and ICP-ES determinations NA = Not applicable.

The average Si value from the hot $\mathrm{HF}_{-} \mathrm{HNO}_{3}$ digestions and the DWPF Cold Chem Method is biased slightly high due to reaction of HF with the quartz nebulizer of the ICP-ES instrument. The average $\mathrm{Li}, \mathrm{K}$, and $\mathrm{Na}$ values are low from both digestions and this is attributed to less than optimum plasma conditions of the ICP-ES instrument. The average Al is slightly low and this is not unusual. All the other elements are within the accepted DWPF ARG Cold Chem Limits. The average results for $\mathrm{Al}, \mathrm{Fe}, \mathrm{Mg}, \mathrm{Mn}$, and Ti from the peroxide fusion digestions are outside the DWPF ARG Fusion limits, which may be indicative of an 
incomplete digestion. The average $\mathrm{Al}$ and $\mathrm{Zr}$ values are low from the aqua regia digestions but the average results of the other elements are good.

\section{Conclusions}

The DWPF Cold Chem Method seems to be effective in dissolving initial species present in radioactive sludge, but during the digestion process mixed-metal fluoride salts are formed and precipitate from solution. CXRD results revealed the identity of the insoluble solids to be mixed-metal fluoride salts. A hot $\mathrm{HF}_{-} \mathrm{HNO}_{3}$ dissolution was successful in dissolving all of the radioactive sludge solids from a visual observation and the only major elements that were statistically different between the DWPF Cold Chem Method and hot the $\mathrm{HF}-\mathrm{HNO}_{3}$ digestion was $\mathrm{Fe}$ and $\mathrm{Sr}$ and it was not a practical difference. A modified version of the DWPF Cold Chem Method, the hot $\mathrm{HF}-\mathrm{HNO}_{3}$ digestion is recommended to ensure all of the solids in the radioactive sludge are being dissolved and stay in solution long enough for analysis.

\section{References}

1. “Analytical Cell System Operating Manual”, SW4-15.201, Section 2.1, Rev.3, effective date $1 / 21 / 2002$.

2. C.J. Coleman, F.M. Pennebaker, B.H. Burch and D.R. Click. "Evaluation of the DWPF Cold Chem Dissolution Method with DWPF Sludge Batch 3 Simulant”, WSRC-TR-0200496, Revision 0.

3. C.J. Coleman. "Alkali Fusion Dissolutions of Sludge and Glass for Elemental and Anion Analysis”, ADS Procedure ADS-2502, November, 2002.

4. C.J. Coleman. “Aqua Regia Dissolution of Sludge for Elemental Analysis”, ADS Procedure ADS-2226, February, 2003.

5. JMP Statistical Discovery Software v 5.0; SAS Institute Inc., Cary, NC, 2002. 